\title{
Strategies Used to Teach Children with ASD at a Public School in Carabayllo (Lima, Peru): Case Study
}

\author{
Martin Fuertes-Requis ${ }^{1}$, Milton Gonzales-Macavilca, ${ }^{2, *}$, Tereza Villegas-Ortiz ${ }^{1}$, \\ Valentina Vargas-Conislla ${ }^{1}$ \\ ${ }^{1}$ Faculty of Humanities Education and Social Sciences, Universidad de Ciencias y Humanidades, Peru \\ ${ }^{2}$ Centre for Interdisciplinary Science and Society Studies, Universidad de Ciencias y Humanidades, Peru
}

Received March 20, 2020; Revised May 12, 2020; Accepted January 25, 2021

\begin{abstract}
Cite This Paper in the following Citation Styles
(a): [1] Martin Fuertes-Requis, Milton Gonzales-Macavilca, Tereza Villegas-Ortiz, Valentina Vargas-Conislla, "Strategies Used to Teach Children with ASD at a Public School in Carabayllo (Lima, Peru): Case Study," Universal Journal of Educational Research, Vol. 9, No. 4, pp. 765 - 770, 2021. DOI: 10.13189/ujer.2021.090408.
\end{abstract}

(b): Martin Fuertes-Requis, Milton Gonzales-Macavilca, Tereza Villegas-Ortiz, Valentina Vargas-Conislla (2021). Strategies Used to Teach Children with ASD at a Public School in Carabayllo (Lima, Peru): Case Study. Universal Journal of Educational Research, 9(4), 765 - 770. DOI: 10.13189/ujer.2021.090408.

Copyright $\bigcirc 2021$ by authors, all rights reserved. Authors agree that this article remains permanently open access under the terms of the Creative Commons Attribution License 4.0 International License

\begin{abstract}
This work aims to learn the strategies used by teachers of a public school in the district of Carabayllo (Lima, Peru) for the teaching of children with ASD. For this, qualitative and exploratory research was carried out. Thus, through a case study, a semi-structured interview was applied to two primary school teachers, and each teacher had a student with ASD in the classroom. Additionally, this data collection was complemented by the non-participatory observation of the researchers, which allowed recording various aspects of the teaching practice, and this in turn helped the description and analysis of the study object. The results showed that teachers, in addition to not having the necessary support and accompaniment, are unaware of the various strategies for inclusive education, so their activities are based, above all, on their intuition and experience. The interviews analysis also reveals that the most important strategy for both teachers was that of teamwork, either with dynamics or games or with the participation of the student with ASD in different groups formed in the classroom. Finally, it is essential to develop more research on this topic, since as a general diagnosis it can be said that public education in Peru at the regular basic level is not yet prepared to ensure the successful incorporation of children with ASD.
\end{abstract}

Keywords Inclusive Education, Autism, Teaching Strategies, Primary Education

\section{Introduction}

Autism spectrum disorder (ASD) is defined by the DSM-V as the difficulty that affects the areas of communication and socialization development. Likewise, the inclusion of children with ASD in regular schools is increasingly frequent, because it seeks to generate an inclusive education that promotes respect for human rights through the integration of all members of society [1], [2].

This requires teachers to take on new challenges, such as teaching autistic children (who, for obvious reasons, exhibit different behaviors or, in other cases, lack of knowledge, difficulties in motor activities and in their social relationships, and even a marked disinterest in educational activities, etc.) [3], [4]. For this, it is essential that teachers know and apply various strategies that favor the integration of all children equally [1], so they must plan and organize the pedagogical strategies that best meet these needs [5].

However, there are several strategies that teachers can use, for example:

- Music therapy, which is used as a tranquilizer to reduce anxiety [6]. It should be noted that the application of each strategy is never homogeneous, since each child is a unique case [7]. So the strategies used by the teachers will also depend on their methodological capacities, on the teaching materials available for them, on the school infrastructure, on the parents support, on the teachers' specialized advice in 
the different characteristics of ASD and the school psychologists support [8], [9].

- Sports practices incorporation is another strategy that provides significant benefits, due to which its application is increasingly recurring [10], [11].

- On the other hand, to address the difficulties of children with ASD in the field of communication, recreational strategies have been used, because the game favors communicative, emotional activities and personality development [12].

- Likewise, in order to promote integration, several strategies have been proposed, among which the use of theater stands out, since it has had favorable results in terms of its effectiveness both in regular children and in those with specific difficulties [13].

- Information and communication technologies (ICT) have also helped to design strategies to improve the social relations of children with ASD, because through these resources they can express their feelings and improve the empathy level with their peers [8].

- Finally, we can mention the strategy called CRA (Concrete-Representational-Abstract), which is interested in cognitive development in students with ASD, and more specifically aims to develop mathematical thinking through drawings because representation Graph allows a better understanding of the study object meaning [14].

There are many others strategies, but the important thing is to understand that to be successful, it is essential to have the joint participation of parents, teachers and the educational institution in general, since they represent socializing agents whose main function is to create an environment of affection, cooperation and awareness that favors inclusive education [15].

All of the above allows us to observe the complexity of this topic and the need to limit research to a particular aspect; Therefore, for this first approach, it was proposed as a general objective to determine the strategies used by teachers for the teaching of children with ASD of the 2nd and 6th grade of primary school in a school in Carabayllo. The following specific objectives were also raised:

- Know the way in which teachers implement the strategies for teaching children with ASD.

- Describe the differences between the strategies used by teachers to teach children with ASD.

Thus, with the results of this research, we seek to offer a general and tentative diagnosis of inclusive education in Peru and promote the investigation of this aspect that is not well attended in regular basic Peruvian education.

\section{Methodology}

This research is of qualitative and exploratory approach
[16]; For this, a case study was carried out focusing on a public school located in a district of Lima Norte (North Lima).

\section{Sample}

Sampling was done by intentional selection of two teachers (one from the 2nd and the other from the 6th grade of primary school) from a public school in the Carabayllo district (Lima-Peru). This selection occurred because these two cases were the only ones that had a student with ASD in their classrooms.

\section{Instruments and data collection}

A semi-structured interview was conducted with each teacher, whose purpose was that respondents could freely express their experiences, thoughts, achievements and difficulties [17] (for example, in the question they were asked: "What strategies for teaching children with ASD do you know?" And in another question: "When you are planning a class session, what strategies do you consider important to arouse the interest of children with ASD?"). It should be noted that for the conduct of the interviews, the relevant ethical procedures were complied with, such as the informed consent of both the educational institution and the teachers interviewed, who have also been coded as follows to respect the anonymity of their testimonies:

- The first teacher interviewed was the primary school second grade, so his coding is: D1-G2.

- The second teacher was the primary school sixth grade, so he received the following coding: D2-G6.

Additionally, this data collection was complemented by the non-participatory observation of the researchers, which allowed recording various aspects of the teaching practice, and this in turn helped the description and analysis of the study object [18].

\section{Results}

The order that will follow the presentation of results will be the following: first, the strategies that teachers say they know for teaching children with ASD will be exposed; then, the way they plan their teaching units will be described; and, finally, the differences that exist between the strategies used by both teachers will be discussed.

\section{A Subsection Sample}

In this analysis category, the interviews allowed to identify three relevant aspects:

1) It was the first time working with children with ASD: The statements of both teachers confirm that the inclusive education policies in Peru are gradually allowing children with different abilities to be 
incorporated [1], [19]; it is therefore crucial to ensure that teachers are prepared for this new educational landscape. The following statements evidence this progress, but they are also proof that it is an initial stage:

As a teacher I had never had an inclusive child in the classroom (D1-G2).

I am a primary school teacher and in all the experience I have, I've never worked with such children, for me it is something new (D2-G6).

2) It was an adaptation case: Although it was the first teacher's experience, one of them mentioned that not all cases of children with ASD are the same. Given this, he said that he had to adapt his work to the child needs:

In my case it was an adaptation matter, socialization and the strategies I used were through simple images, to find that he works from what he knows (D1-G2).

We observe the need felt by the teacher to adapt his strategies in order to facilitate the adaptation of the child with ASD to the study environment [5], [7]. These statements allow us to give way to the following aspect.

3) Strategies that teachers know: Teachers always have the need to increase their pedagogical skills to be able to address their students' diversity [20]; however, methods that can work with regular children do not necessarily work for children with ASD. This requires teachers to investigate, modify or adapt strategies they already know or, in other cases, to create or investigate new and different methods. Unfortunately, this ideal is not always fulfilled, as seems to happen with the cases interviewed:

The dynamics we use are born from the situation and the planned ones are based on the experience (D2-G6).

The Servicio de Apoyo y Asesoramiento a las Necesidades Educativas Especiales (The Service of Support and Advice to the Special Educational Needs - SAANEE) sent us strategies sporadically, such as to recognize, identify, select (D1-G2).

This reveals that teachers are not specialists in inclusive education, who know little about the strategies to educate children with ASD; and many times they must improvise based on the "sporadic" to help them receive (D1-G2), but especially on their own observations, experiences and criteria. Even so, the strategies mentioned by the teachers were:

$[\ldots]$ the strategies I used were through simple images, to find that he works from what he knows (D1-G2).

In the strategies that I use, we make sheets in which the children mention the classmates' characteristics or names of friends, families or the things they like [...] and I use mimicry because he has a speech problem. I also use success strategies, we never rate him badly, he works with the encouragement of receiving a grade of A to be happy (D2-G6).

It can be seen that the case of D1-G2 tries to take advantage of previous knowledge, things that children with ASD can identify or know; on the other hand, the D2-G6 has more diverse resources. Therefore, it is interesting to analyze how they plan their classes.

\section{Class planning for children with ASD}

It is essential that in order to teach a class, the teacher previously carries out a planning with the objective of structuring each element according to their students' level [21], especially if they have a child with ASD in the classroom. In this regard, teachers said that:

The first thing is to adapt the session to reality, meet the requirement, but achieve the ability by making it smaller by regulating it to the minimum according to the child. In my case I did it as I could (D1-G2).

When I plan my classes I take my learning unit and I disaggregate, underline and highlight the gradualness level of aspects that correspond to that child [...] I must bring differentiated [material] for him (D2-G6).

It can be said that although both teachers plan their classes, D2-G6 goes deeper into this process ("disaggregation, underline, highlight"), however D1-G2 although it recognizes the importance of adapting the session, reveals limitations and lack of support ("I did it as I could"). This, as seen above, is related to the greater strategies number that D2-G6 claims to know and use in the classroom.

To continue with this comparative reading, the last block corresponding to the results is presented.

Differences between the strategies used for teaching children with ASD

Achieving the inclusive education objectives (making children with ASD feel included, useful and safe, and being able to interact with their social context [22]) can produce a double satisfaction effect, both in the student and in the teacher, as the following testimony:

He loves [the student with ASD] computing, I sat next to him and through a follow-up I spelled the letters and he wrote it, he knew the keyboard and was the one who pulled the images. I saw him happy. It was a pleasure for him and me because he felt good (D1-G2).

In this case, the use of technological tools served to fulfill the inclusive education objective. But psychomotor activities, according to the same teacher, can facilitate the student integration with his classmates:

Interviewer: What other strategy did you find favorable? 
In my case, in the classroom what he liked most was the motor part, for example, in physical education he participated in the dynamics, he kept the ball, followed the sequences he saw in classmates. Everything that is bodily expression he did (D1-G2).

Then, for the second-grade teacher, the fusion of technological and physical strategies [8], [10] has a positive impact on the education of children with ASD. Moreover, he said that mixing these physical activities with music (that is, the dance strategy) has a very positive impact, as it even helps to regulate certain aggressive behaviors that students with ASD can present [23]:

[...] It wasn't just any music that motivated him, but the dances, when I select another rhythm he got frustrated and his head started to ache [...] I would use the music resource as a regulator on behavioral issues because motor expressions, in my case, I know that they work. It is like a regulator or a way to calm it (D1-G2).

On the other hand, although the sixth-grade teacher did not mention the technologies use, he did agree with his colleague regarding physical activities:

[...] As for his motor activities, very good. They are developed by the physical education teacher, [who] takes him as an ordinary child in the classroom (D2-G6).

In addition, he stressed that integration strategies have an even more favorable impact, as they help the students with ASD not to depend on the teacher:

What we normally do in the classroom is teamwork, we do a weekly raffle, [and the student with ASD] is integrated into different teams, is rotating and socializing; that is, he meets his friends in such a way that the impact he has is respect for his teammates.

Interviewer: Do you monitor the child in each group?

I give certain rules to his classmates, if they don't help him they stay at break every time he makes a mistake, so they worry and make him erase, correct and let me know. He has become accustomed to that form of work. He doesn't need me to be by his side (D2- G6).

Social interaction is one of the many problems associated with ASD, and as can be seen from the statements of D2-G6, this strategy also helps other regular students live together and, therefore, become aware of the importance of supporting their partner with ASD. In that sense, this would be one of the most powerful strategies because it fosters an integral education, promotes dialogue and respect for the agreements that the teacher poses with the students themselves [24]. Even, according to the same teacher, this strategy favors the aggressive behaviors self-regulation:

Behaviorally, initially the child [with ASD] presented some difficulties, but with that teamwork and socialization has managed improve almost one hundred percent. That child does not have violent behavior in the classroom [...] (D2-G6).

Undoubtedly, this also has to do with the empathy development, both the student-student relationship and the teacher-student relationship [24]. And on this aspect, the second-grade teacher opinion is similar, but highlights that this is a complicated process:

I always try to work with the children the empathetic part, I think that when you are gentle with a child, they become more attached to you and attend class better [...]. In the case of children with ASD, managing to create bonds with their teachers is sometimes, somewhat complicated, because of their defects, they do not receive good affective treatment and that frustrates their learning (D1-G2).

The last mentioned lines open a more complex dimension on the topic of the education of children with ASD. That the teacher himself says that the student with ASD has "defects" requirements, at a minimum, to carry out other research that helps to understand what teachers think of students with ASD. This time this aspect will not be discussed, both for reasons of space and because the objective set for this work is another. Leaving that aside, the teacher affirms that affectionate treatment is essential to generate links that favor education:

[...] It is advisable not to be authoritarian like the traditional school, because there are cases [of teachers] who shout and mistreat [children with ASD]. To me that seems very bad, if you treat a child with love and affection, he will regulate himself. [...] I work a lot on the emotional part based on the love pedagogy; in these cases that is the first thing that should work (D1-G2).

It is clear that all these strategies referred to by teachers, despite the differences that have been pointed out, coincide in a worrying aspect: neither case reveals a real and deep knowledge of appropriate strategies for an inclusive education. As they themselves have said, they do what they can.

\section{Conclusions}

From the results it can be concluded that the teachers of this public educational institution in Carabayllo have not received the proper preparation and / or support to teach children with ASD. None of the cases studied have not had previous experience with these types of students.

Faced with this situation, they had to "do what they could" according to the situations that were presented. However, the planning of the sessions was a fundamental activity for both two. Although D2-G6 case proved to know more teaching strategies for children with ASD, in practice the difference in the amount of strategies 
implemented was not as representative as in D1-G2 case.

The interviews analysis also reveals that the most important strategy for both teachers was that of teamwork, either with dynamics or games (D1-G2) or with the participation of the student with ASD in different groups formed in the classroom (D2- G6).

The differences between the practices of both teachers are related, above all, to the complementary strategies they use (D1-G2: technology and dance; D2-G6: sport and the collaborative participation of other students). Despite these small differences, both teachers showed a real concern that students with ASD will be included, integrated and respected by their classmates.

Finally, it is essential to develop more research on this topic, since as a general diagnosis it can be said that public education in Peru at the regular basic level is not yet prepared to ensure the successful incorporation of children with ASD. Teachers do not know in depth the various strategies, and they do what they can even if they are often guided solely by their intuition; that is, they need to receive adequate training, advice and support. This is easily demonstrated by the fact that the teacher insinuates (perhaps unconsciously, which is even more serious) that a student with ASD has "defects".

\section{REFERENCES}

[1] L. Gomez, R. Castillo, A. Camacho, Y. Sánchez, and C. Álvarez, "Análisis de las actitudes y prácticas inclusivas en República Dominicana," Revista Nacional e Internacional de Educación Inclusiva, vol. 10, nº 1, pp. 181-198, May. 2017.

[2] S. Carrington, D. Tangen and D. Beutel, "Inclusive education in the Asia Indo-Pacific region," International Journal of Inclusive Education, vol. 23, $\mathrm{n}^{\mathrm{o}}$ 1, pp. 1-6, Aug. 2019.

[3] L. Vázquez, C. D. Rivas, E. Meléndez, J. S. Magrináá and N. I. Méndez, "Revisión del trastorno del espectro autista: actualización del diagnóstico y tratamiento," Revista Mexicana de Neurociencia, vol. 18, $\mathrm{n}^{\circ}$ 5, pp. 31-45, Sep. 2017.

[4] O. M. Rolim, V. L. Fialho and A.P. Moraes, "Variáveis pessoais de professores para o atendimento a alunos com transtorno global do desenvolvimento," Revista Educação Especial, vol. 30, n⿳0 59, pp. 81-695, Sep. 2017.

[5] A. Rangel, "Orientaciones pedagógicas para la inclusion de niños con autismo en el aula regular: Un apoyo para el docente," TELOS, vol. 10, n 1, pp. 81-102, Oct. 2017.

[6] D. Garrote, G. Pérez and R. M. Serna, "Efectos de la Musicoterapia en el Trastorno de Espectro Autista," Revista Nacional e Internacional de Educación Inclusiva, vol. 11, $\mathrm{n}^{\mathrm{o}}$ 1, pp. 175-192, Jun. 2018.

[7] C. Carrasco, R. Flores and A. Caballer, "Evalución y adapatación de la orientación vocacional/ profesional del alumnado con diversidad en educación secundaria en un contexto inclusivo," Revista de Orientación Educacional, vol. 31, n 59, pp. 7-22, Jun. 2017.

[8] S. García, D. Garrote and S. Jiménez, "Uso de las TIC en el Trastorno de Espectro Autista: aplicaciones," Edmetic, vol. $\mathrm{x}, \mathrm{n}^{\mathrm{o}} \mathrm{x}$, pp. 134-157, Sep. 2016.

[9] I. A. Peña, T. Massetti, T. Brusque, T. Dias, L. Menezes, C. Bandeira and F. Magalhães, "Motor learning characterization in people with autism spectrum disorder," Dementia \& Neuropsychologia, vol. 11, n 3, pp. 276- 286, Sep. 2017.

[10] G. Fessia, D. Manni, L. Contini and F. Astorino, "Estrategias de actividad física planificada en autismo: revisión sistemática," Salud Pública, vol. 20, nº 3, pp. 390-395, Feb. 2018 .

[11] P. Benitez, M. Carvalho, R. Bondioli and C. Domeniconi, "Mapping of inclusive strategies for students with intellectual disabilities and autism," Psicologia em Estudo, vol. 22, no 1, pp. 81-93, Jan. 2017.

[12] G. Moreno and C. Ximena, "El juego como estrategia para el desarrollo del lenguaje en un niño con trastorno del espectro autista desde el ámbito de la educación inclusiva," Revista de la Investigación Educativa de la Rediech, vol. 9, n 17, Oct. 2018.

[13] M. Calafat, P. Sanz Y R. Tárraga, "El teatro como herramienta de intervención en alumnos con trastorno del espectro autista y discapacidad intelectual," Revista nacional e internacional de Educación Inclusiva, vol. 9, no 3, pp. 95-108, Noviembre 2016.

[14] I. Polo, A. Bruno, M. J. González y B. Olivera, "Estrategias y representaciones en la resolución de problemas aritméticos de división en estudiantes con trastorno del espectro autista: un estudio de caso," Revista Nacional e Internacional de Educación Inclusiva, vol. 11, n² 2, pp. 159-178, Enero 2018.

[15] Y. Zaldivar, J. Martínez y Y. Demósthen, "Estrategia pedagógica para la inclusión educativa del escolar con trastorno del Espectro De Autismo," Opuntia Brava, vol. 11, Febrero 2019.

[16] M. A. Guerrero, "La Investigación Cualitativa," Innova, vol. 1, no 22, pp. 1-9, 2016.

[17] J. A. Taguenca, "Tecnica de Investigacion Social las entrevistas abierta y semidirectiva," Nueva Época, vol. 1, $\mathrm{n}^{\circ}$ 1, pp. 58-94, 2012.

[18] R. Stake, "Investigación con estudio de casos,” 1998.

[19] Cueto, S., Rojas. V., Dammert, M Y Felipe, C., "Cobertura, oportunidades y percepciones sobre la educación inclusiva en el Perú," GRADE (Documentos de Investigación, 87), Lima, 2018.

[20] F. Gonzalez-Gil., E. Martín-Pastor Y R. Poy, “Educación inclusiva: barreras y facilitadores para su desarrollo. Análisis desde la percepción del profesorado," Profesorado, vol. 23, n 1, Enero-Marzo 2019.

[21] V. Garcia, "La planificación docente y la práctica de juegos sexistas en el nivel inicial de la unidad educativa Kasama (Tesis de pregrado)," 2018.

[22] M. Calderón, "La educación inclusiva es nuestra tarea," Educación, vol. XXI, nº 40, pp. 43-58, Marzo 2012. 
[23] M. Tudela Y L. Abad, "Reducción de las conductas autolesivas y autoestimulatorias disfuncionales en los transtornos del espectro del autismo a través de la terapia ocupacional," Medicina, vol. 79, pp. 38-43, 2019.
[24] D. Cortés, "La tutoría entre pares y los estilos de aprendizaje como estrategias significativas en el proceso de enseñanzaaprendizaje," Braz. J. of Develop., Curitiba, vol. 5, nº 6, pp. 6752-6762, Junio 2019. 